\title{
Seasonal variation of reproductive traits of the caramote prawn in the Gulf of Tunis
}

\author{
Hela JAZIRI $^{1}$, Rosalia Ferreri ${ }^{2}$, Widien KHOUfi ${ }^{1}$, Safouene El FeHri ${ }^{1}$, Sadok Ben Meriem ${ }^{1}$, \\ Maurizio PULIZzI ${ }^{2}$, Salvatore MANGANO ${ }^{2}$, Angelo BONANNO ${ }^{2}$, Salvatore MAZZOLA ${ }^{2}$ \\ and Gualtiero BASILONE ${ }^{2, a}$ \\ 1 National Institute of Sciences and Marine Technologies (INSTM), Port La Goulette, 2060 Tunis, Tunisia \\ ${ }^{2}$ Institute for Coastal Marine Environment of the National Research Council (IAMC-CNR), Capo Granitola Via del Mare 3, 91021 Torretta \\ Granitola, Campobello di Mazara (TP), Italy
}

Received 10 July 2015; Accepted 14 January 2016

\begin{abstract}
The caramote prawn, Melicertus kerathurus, is a Penaeidae species inhabiting the Mediterranean Sea and the Est Atlantic Ocean. Caramote prawn represents a commercially important species in terms of both aquaculture and fishing; however, there is poor information on its reproductive biology in Mediterranean and, particularly, in Tunisian waters. To fulfil such a gap, monthly samples of caramote prawn were collected along the northern Tunisian coast throughout one year. Ovaries maturity data, obtained by histological analysis, together with reproductive and condition indices, indicated the main spawning season extends from April to August, with a clear peak in July-August. However, gonadic production still persists during September-December, although at lower levels. The seasonal patterns of somatic and gonadic conditions suggested that energy reserves, during the main spawning period, were invested both in gonadic and body production; but males and females appeared to devote differently such energy reserves. During the spawning peak, females revealed both good somatic and gonadic conditions simultaneously, while males displayed worse body conditions. Monthly sea surface temperature (SST) showed a high level of pattern correspondence with ovary maturity phase and gonadosomatic index (GSI); but a strong linear relationship between SST and GSI in the study area was observed only for males. Such results increased reproductive biology knowledge, therefore allowing to improve the management quality of both wild caramote prawn stocks and reared populations.
\end{abstract}

Keywords: Melicertus kerathurus / sexual maturity / histological analysis / spawning season / length at first maturity

\section{Introduction}

Melicertus kerathurus (Forskäl 1775), known as caramote prawn, is a demersal crustacean, widely distributed in the Mediterranean Sea and the eastern Atlantic, from the south coast of England to Angola (Holthuis and FAO 1980; Dore and Frimodt 1987). Crustaceans are composed by 7 groups. Among them, shrimps and prawns constitute the most commercially important group, because they represent $51 \%$ of crustacean world capture production and $4 \%$ of total world capture production (FAO 2010). Particularly, caramote prawn is one of the most exploited crustacean species by fishery in the Mediterranean Sea and, especially, in Tunisia (Chaouachi and Ben Hassine 1998). This species is fished along the whole Tunisian coastline by trawling both at industrial and artisanal fleet levels (Bedioui et al. 2004).

Since '30s (Heldt 1932), caramote prawn was thoroughly studied in Tunisia, focusing on aspects related to dynamic,

a Corresponding author: gualtiero.basilone@iamc.cnr.it exploitation, fisheries technologies and genetics (e.g., Ben Meriem 1993, 1995, 1998; Zitari-Chatti et al. 2008). Despite these studies, few papers deal with reproductive biology of caramote prawn in the Gulf of Gabès (Heldt 1938; Ben Mustafa 1967; Ben Meriem 1993), and even no data exist in the Gulf of Tunis. Information on reproductive traits, as spawning behaviour and reproductive strategies, are basic prerequisites to establish suitable measures for stocks management (Marshall et al. 2003; Joaquim et al. 2008; Butler and Rowland 2009; Reñones et al. 2010). For the same purposes, length at first maturity and sex ratio estimations are also useful to determine reproductive potential and spawning pattern of fish (Coleman et al. 1996; Trippel 1999; McBride et al. 2015) and crustacean species (Pillay 1964; Potter et al. 1983).

Penaeid prawns have a wide distribution in both temperate and tropical seas (Garcia and le Reste, 1981; Crocos and van der Velde 1995; de Freitas 2011; Munga et al. 2013). Penaeid species, distributed in tropical and sub-tropical areas, have two main spawning periods: in spring and in autumn; while, penaeid species inhabiting temperate latitudinal zones 


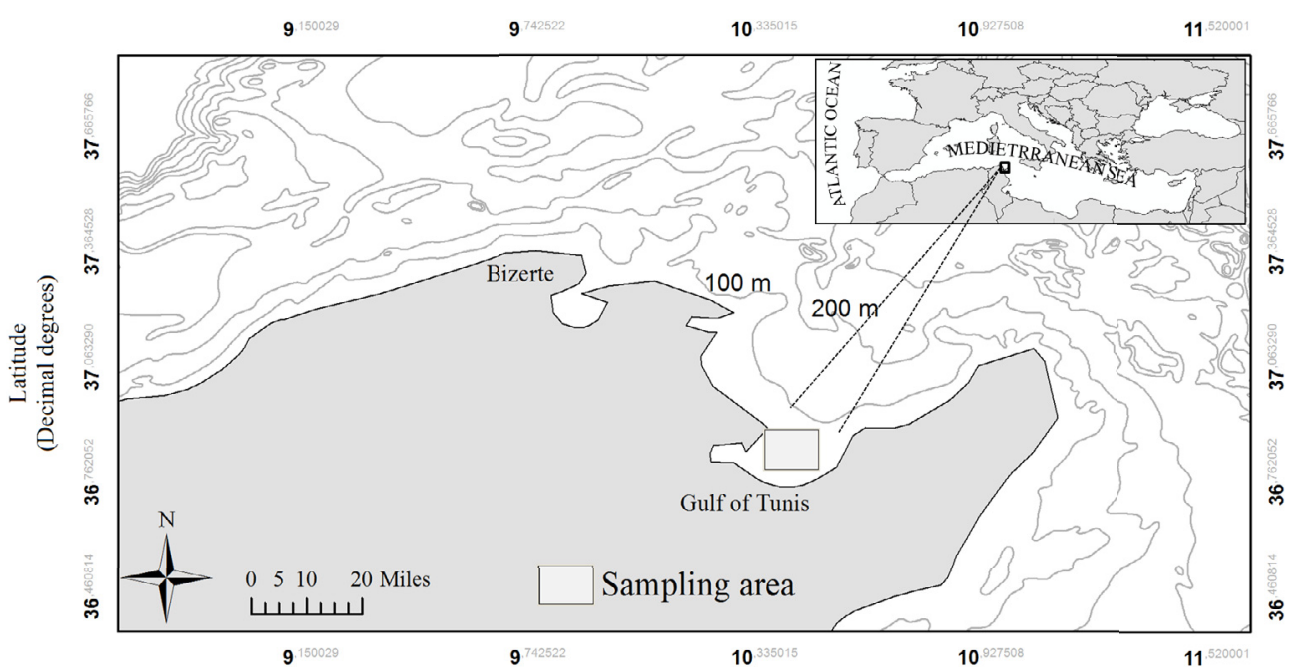

Fig. 1. The study area with indication of the main bathymetry. The square highlights sampling area.

are characterized by unimodal seasonal spawning, with only one well-defined recruitment (Crocos and van der Velde 1995). According to literatures, reproductive dynamics of caramote prawn is known to be influenced by temperature, rainfall, and depth (Dall et al. 1990; Crocos et al. 2001).

Several studies demonstrate how crustaceans in aquaculture domain are important, as well as how the knowledge of reproductive biology is necessary to enable successful culture for food purposes (San Feliu et al. 1976; Rodriguez 1977; Klaoudatos 1984; Lumare 1998). To this aim, in the present work traits of reproductive biology of wild stock of caramote prawn were investigated: reproductive strategy and energy investment are studied by observing seasonal evolution of somatic and gonadic condition together with the main environmental constraints, such as sea surface temperature evolution.

\section{Materials and methods}

Data from 596 wild individuals of caramote prawn (304 females and 292 males) were obtained by commercial trawlers landings. Sampling took place once a month from May 2011 to April 2012 in the Gulf of Tunis within the depth range 20$100 \mathrm{~m}$ (Fig. 1).

For each individual, total length (TL) $( \pm 0.5 \mathrm{~cm})$, carapace length $(\mathrm{CL})( \pm 0.5 \mathrm{~cm})$, total weight (TW) $( \pm 0.1 \mathrm{~g})$, eviscerated weight $(\mathrm{EW})( \pm 0.1 \mathrm{~g})$, gonad weight $(\mathrm{GW})( \pm 0.001 \mathrm{~g})$, and sex were recorded. Maturity phase of ovaries was visually determined according to macroscopic features (Farmer 1974).

Dissected ovaries were preserved in $10 \%$ buffered formaldehyde until they were later processed in the IAMC laboratories to prepare gonadic tissues thin sections. Slides were attained by means of standard paraffin embedding and Haematoxylin-Eosin staining method, with a slice thickness of 4 micron (Gil et al. 2013; Basilone et al. 2015). Spawning phase determination was microscopically carried out according to the five-class scale proposed by Medina et al. (1996): immature (phase I), developing (phase II), maturing (phase III), mature (phase IV), and spent (phase V).
A nonparametric test for a two-group comparison (MannWhitney $U$ test) was applied to evaluate differences in size distribution (TL, CL, TW and EW) between males and females. Moreover, a Kruskal-Wallis ANOVA test was performed for each sex separately to assess significant monthly differences in size distribution. An analysis of covariance (ANCOVA), taking the weight (logarithm) as covariate and length as predictor, was carried out to evaluate size differences between males and females.

Average sex ratio (SR) was obtained by number of females on total number of individuals and its variability, considering season and body size, was also analysed by mean of linear regression technique.

Length-weight relationship of caramote prawn was determined, for males and females separately, by the equation:

$$
T W=a T L^{b}
$$

where $a$ is intercept, and $b$ is slope.

Monthly evolution of somatic conditions was also estimated through the relative condition factor (CF) (Le Cren 1951):

$$
C F=\frac{T W}{a T L^{b}}
$$

where $a$ and $b$ are, respectively, intercept and slope obtained from the previous relationship between TW and TL.

Monthly evolution of the proportion of each reproductive phase, assigned by microscopic classification, was considered to identify caramote prawn spawning peaks.

Reproductive seasonality was also evaluated using the gonadosomatic index (GSI):

$$
G S I=\frac{G W}{E W} \times 100 .
$$

Sea surface temperature (SST) data, provided by the national oceanic and atmospheric administration (NOAA) (ftp://ftp. emc.ncep.noaa.gov/cmb/sst/oimonth_v2/), were employed to assess the onset seasonal timing of caramote prawn reproductive state with respect to average SST. To analyse the relationship between GSI, CF and SST, the reproduction data were separated for sexes. 
Table 1. Summary table with monthly information on collected samples. No. (f): number of sampled females; No. (m): number of sampled males; TL: total length; CL: carapace length; TW: total weight; EW: eviscerated weight.

\begin{tabular}{ccccccccccc}
\hline \multicolumn{1}{l}{ Female } & \multicolumn{10}{c}{ Male } \\
\hline Month & $\begin{array}{c}\text { No. } \\
(\mathrm{f})\end{array}$ & $\begin{array}{c}\text { TL range } \\
(\mathrm{cm})\end{array}$ & $\begin{array}{c}\text { CL range } \\
(\mathrm{cm})\end{array}$ & $\begin{array}{c}\text { TW range } \\
(\mathrm{g})\end{array}$ & $\begin{array}{c}\text { EW range } \\
(\mathrm{g})\end{array}$ & $\begin{array}{c}\text { No. } \\
(\mathrm{m})\end{array}$ & $\begin{array}{c}\text { TL range } \\
(\mathrm{cm})\end{array}$ & $\begin{array}{c}\text { CL range } \\
(\mathrm{cm})\end{array}$ & $\begin{array}{c}\text { TW range } \\
(\mathrm{g})\end{array}$ & $\begin{array}{c}\text { EW range } \\
(\mathrm{g})\end{array}$ \\
\hline MAY11 & 19 & $12.5-17.5$ & $2-4$ & $19.31-40.98$ & $17.35-35.84$ & 66 & $9-15$ & $1.5-3.5$ & $09.93-25.95$ & $08.00-24.10$ \\
JUN11 & 10 & $17-20.5$ & $4-4.5$ & $42.84-65.48$ & $38.31-56.51$ & 21 & $13.5-16.5$ & $2.5-3.5$ & $18.36-33.80$ & $17.31-30.98$ \\
JUL11 & 12 & $16.5-18.5$ & $3.5-4.5$ & $35.60-55.63$ & $33.40-47.39$ & 48 & $12.5-17$ & $2.5-3.5$ & $10.47-24.14$ & $09.76-22.33$ \\
AUG11 & 20 & $15-19$ & $3-4.5$ & $27.09-60.50$ & $24.12-53.60$ & 7 & $11.5-14$ & $2.5-3$ & $13.66-19.58$ & $12.26-19.09$ \\
SEP11 & 37 & $13-20$ & $3-5$ & $21.77-68.13$ & $19.18-57.90$ & 6 & $11-14.5$ & $2-3$ & $11.21-24.08$ & $10.44-22.41$ \\
OCT11 & 33 & $14-21$ & $3-5$ & $20.50-74.38$ & $19.72-65.10$ & 38 & $11.5-15.5$ & $2.5-3$ & $14.95-28.93$ & $12.69-27.77$ \\
NVB11 & 21 & $15.5-21.5$ & $3-5.5$ & $29.39-85.70$ & $27.09-76.18$ & 17 & $13.5-17$ & $2.5-3.5$ & $21.19-37.92$ & $19.70-35.56$ \\
DEC11 & 17 & $17-21$ & $4-5.5$ & $41.65-86.37$ & $37.81-76.26$ & 18 & $13.5-17$ & $2.5-3.5$ & $20.84-39.02$ & $19.15-35.44$ \\
JAN12 & 20 & $17-21.5$ & $3.5-5.5$ & $37.31-86.77$ & $34.99-79.98$ & 8 & $15-17.5$ & $3-3.5$ & $25.60-41.11$ & $24.35-39.46$ \\
FEB12 & 49 & $17-21.5$ & $2.5-5.5$ & $13.80-79.05$ & $11.70-70.95$ & 37 & $13-17$ & $2.5-3.5$ & $16.92-38.86$ & $15.86-36.48$ \\
MAR12 & 43 & $11.5-17.5$ & $2-4$ & $12.04-41.71$ & $11.73-39.93$ & 19 & $12-15.5$ & $2.5-3$ & $14.48-28.49$ & $13.48-27.29$ \\
APR12 & 23 & $13.5-18.5$ & $3-4.5$ & $20.97-59.21$ & $19.46-51.24$ & 7 & $12-14$ & $2.5-3$ & $12.95-22.46$ & $12.27-21.08$ \\
Overall & $\mathbf{3 0 4}$ & $\mathbf{1 1 . 5}-\mathbf{2 1 . 5}$ & $\mathbf{2 - 5 . 5}$ & $\mathbf{1 2 . 0 4 - 8 6 . 7 7}$ & $\mathbf{1 1 . 7 0 - 7 9 . 9 8}$ & $\mathbf{2 9 2}$ & $\mathbf{9 - 1 7 . 5}$ & $\mathbf{1 . 5}-\mathbf{3 . 5}$ & $\mathbf{0 9 . 9 3 - 4 1 . 1 1}$ & $\mathbf{0 8 . 0 0 - 3 9 . 4 6}$ \\
\hline
\end{tabular}

Microscopic and macroscopic examinations of maturity stage were compared by evaluating the proportion of correspondence between each reproductive phase.

Length at which $50 \%$ of individuals were mature $\left(L_{50}\right)$ was estimated considering mature individuals as those belonging to the spawning phases III, IV, and V by a logistic nonlinear regression model (Basilone et al. 2006). Two different $L_{50}$ curves were appraised by means of data respectively from both macroscopic and microscopic reproductive phase determination. According to ICES (2008) recommendations on maturity ogive estimation, curves were fitted using data from individuals sampled during the main spawning period.

\section{Results}

\subsection{Body size and sex ratio}

Linear relationship between total and carapace length $\left(C L=0.30 T L-1.17 ; r^{2}=0.93\right)$ as much as between total and eviscerated weight $\left(E W=0.85 T W+1.75 ; r^{2}=0.97\right)$ showed high correlation, suggesting to use TL and TW as proxies of respectively $\mathrm{CL}$ and $\mathrm{EW}$ for subsequent analyses.

Overall size distribution revealed marked differences between the two sexes both in length and weight (Table 1). A Mann-Whitney $U$ test confirmed significant differences in TL, CL, TW, EW (Table 2), as also suggested by their well separated monthly trends (Fig. 2). Monthly differences throughout the study period were confirmed by a Kruskal-Wallis ANOVA test, carried out for each sex separately (Table 3). Conversely, size monthly trends for each sex presented high agreement levels for all the above variables, increasing firstly from March to July, and again with higher rate until January when they started to decrease. Lower values were reached in March for females and April for males (Fig. 2).

As expected from previous observation, also the length-weight relationships obtained for females $(T W=$ $\left.0.009 T L^{2.9746} ; r^{2}=0.94\right)$ and males $\left(T W=0.0154 T L^{2.7445}\right.$; $\left.r^{2}=0.88\right)$ showed significant differences $\left(F_{1,545}=79.22\right.$; $p<0.001)$.
Table 2. Mann-Whitney $U$ test for the significance of differences between sexes for body size and condition and reproductive indices.

\begin{tabular}{ccc}
\hline & $U$ & $Z$ \\
\hline TW & 7626 & $-15.99^{*}$ \\
TL & 12937 & $-14.96^{*}$ \\
CL & 8429 & $-17.11^{*}$ \\
EW & 8710 & $-16.98^{*}$ \\
GSI & 14079 & $-14.43^{*}$ \\
CF & 7626 & $-17.49^{*}$ \\
\hline
\end{tabular}

${ }^{*} p<0.001$; TW: total weight; TL: total length; CL: carapace length; EW: eviscerated weight; GSI: Gonadosomatic index; CF: condition factor.

Table 3. Kruskal-Wallis ANOVA test for the significance of monthly differences along the study period for body size, condition and reproductive state.

\begin{tabular}{lcccc}
\hline \multicolumn{2}{c}{ Male } & \multicolumn{2}{c}{ Female } \\
\hline & Chi-square & $P$ & Chi-square & $P$ \\
\hline TW & 105.60 & $0.00^{*}$ & 66.02 & $0.00^{*}$ \\
TL & 106.03 & $0.00^{*}$ & 66.26 & $0.00^{*}$ \\
CL & 43.41 & $0.00^{*}$ & 70.70 & $0.00^{*}$ \\
EW & 123.32 & $0.00^{*}$ & 67.22 & $0.00^{*}$ \\
GSI & 75.11 & $0.00^{*}$ & 101.11 & $0.00^{*}$ \\
CF & 80.33 & $0.00^{*}$ & 30.61 & $0.00^{*}$ \\
\hline
\end{tabular}

${ }^{*} p<$ 0.001; TW: total weight; TL: total length; CL: carapace length; EW: eviscerated weight; GSI: Gonadosomatic index; CF: condition factor.

Along the study period, SR ranged from 0.2 to 0.86 and both sexes underwent similar fluctuation from August onward, while during May, June and July the number of females was particularly poor (Fig. 3a). Sex ratio evolution vs. size revealed a prevalence of males between 11 and $15 \mathrm{~cm}$ TL, while individuals longer than $17 \mathrm{~cm}$ were only females (Fig. 3b). Monthly variability of SR did not appear directly related to TL as the coefficient of determination was very low $\left(r^{2}=0.05\right)$. 


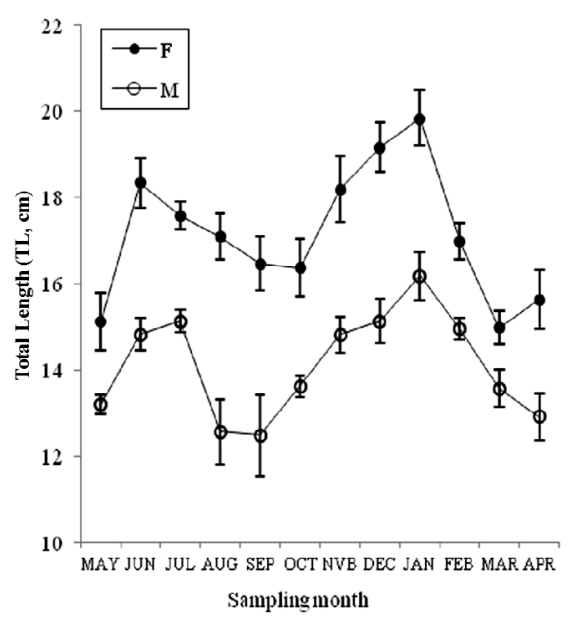

(a)

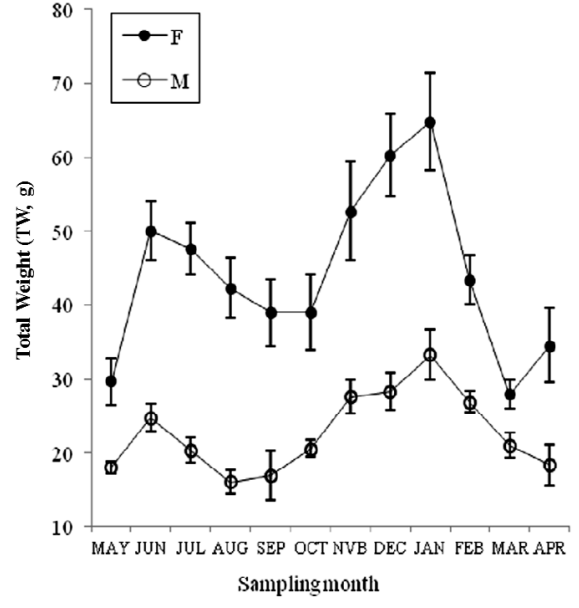

(b)

Fig. 2. Monthly evolution of average body measures of caramote prawn with their confidence limits plotted for each sex (F: females; M: males): (a) total length (TL, in cm); (b) total weight (TW, in $\mathrm{g}$ ).

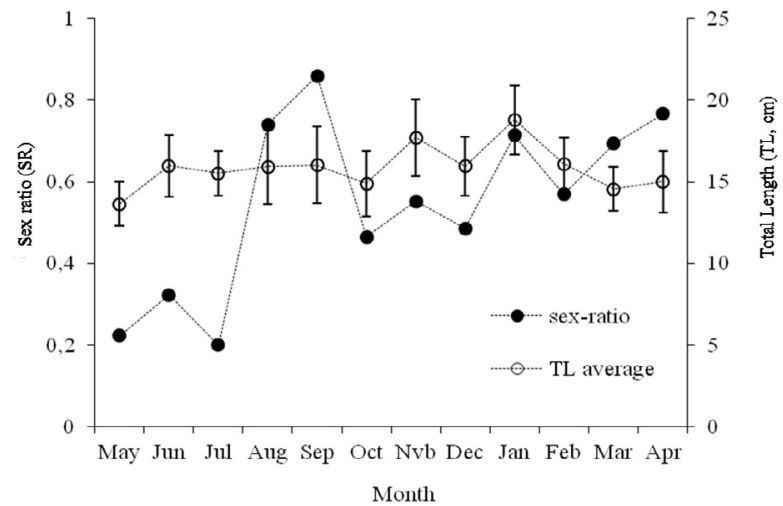

(a)

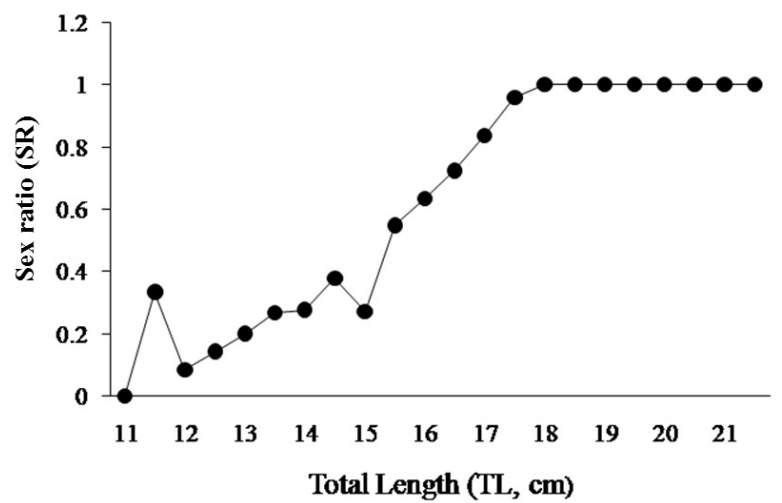

(b)

Fig. 3. (a) Caramote prawn monthly average total length (TL, in $\mathrm{cm}$ ) together with their confidence limits and sex ratio (SR) monthly evolution, provided in order to evaluate SR variability with respect to length variability along the study period. (b) Sex ratio data variability along the observed size range of caramote prawn.

\subsection{Spawning patterns and somatic condition}

CF overall values showed significant differences between sexes (Table 2), and they exhibited also different monthly trends (Table 3). However, for both sexes lower values were observed in May and June, while from July onwards body condition appeared fairly stable (Fig. 4a).

Although GSI varied significantly both among sexes and months (Tables 2 and 3), its monthly trends were comparable along the study period (Fig. 4b). In both sexes, GSI evolution indicated a clear seasonal pattern, displaying higher values in spring and summer when spawning peak takes place (July-August) while from August to September, there was an abrupt decrease. Successively, up to December there were stable trends showing the persistence of spawning activity, although reduced, as a tail of the spawning season. Finally from January onwards, GSI values for females decreased reaching its minimum in March, opposite to the males trend (Fig. 4b).

According to microscopic maturity determination the main spawning period of caramote prawn extended between April and August when majority of females (83.33\%) were actively spawners (phase IV). However, some evidence of spawning was also observed until December (Fig. 5), while from January to March only immature and maturing gonads were recorded (Fig. 5).

During the spawning peak (July-August), SST reached its annual maximum. However, caramote prawn appeared to spawn also at a lower temperature $\left(\sim 19^{\circ} \mathrm{C}\right)$ during September and December; while in the winter period (January-March), when temperature ranged from 14.6 to $15.4{ }^{\circ} \mathrm{C}$, GSI was at its lowest levels (Fig. 5).

The correlation analysis between biological parameters (CF and GSI) carried out for females did not show significant results both in summer and in autumn $\left(r^{2} \leqslant 0.3\right)$. Opposite, for males the relationship between CF and GSI was statistically significant in both seasons, but it was decreasing in AprilAugust $\left(r^{2}=0.73\right)$ and increasing in September-December $\left(r^{2}=0.83\right)$ (Fig. 6a). The SST evolution pattern matched GSI trend in both sexes, although their relationship was significant only for males in both periods $\left(r^{2}=0.5\right.$ in April-August and $r^{2}>0.8$ in September-December, respectively) (Fig. 6b). 


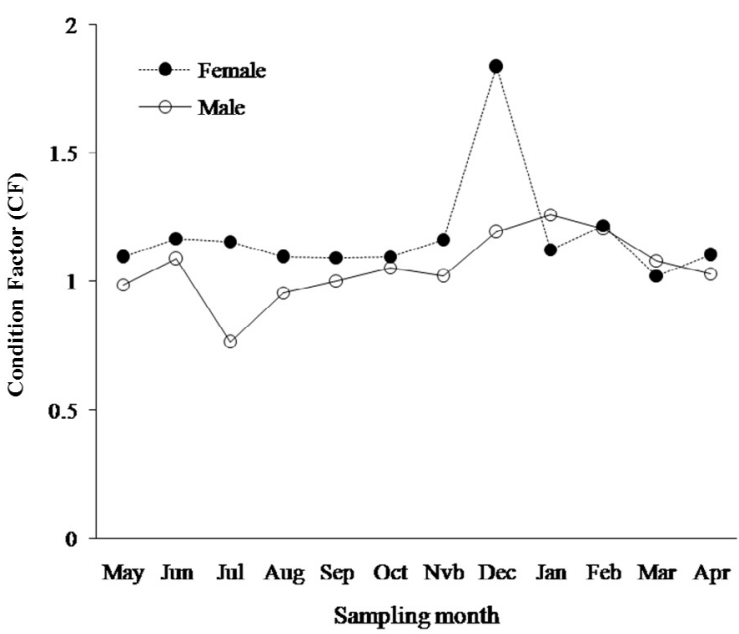

(a)

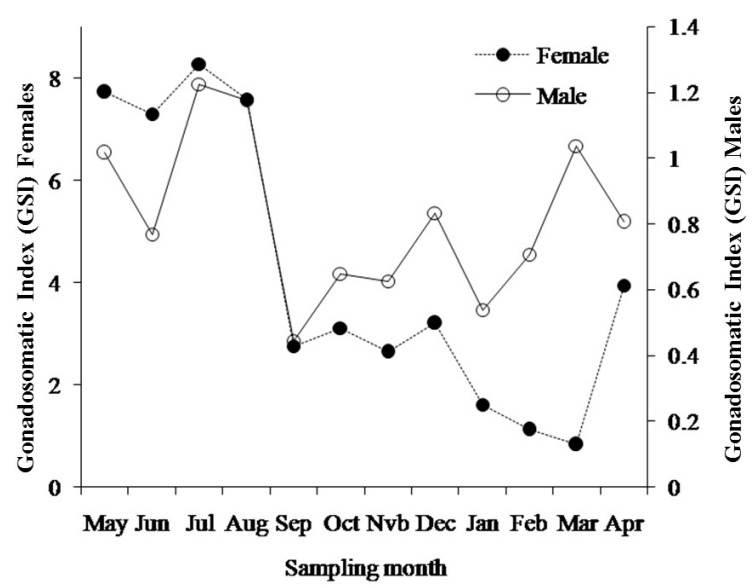

(b)

Fig. 4. (a) Evolution of condition factor (CF) (Le Cren 1951) obtained for each sex (F: females; M: males). (b) Evolution of gonadosomatic index (GSI) obtained for each sex (F: females; M: males).

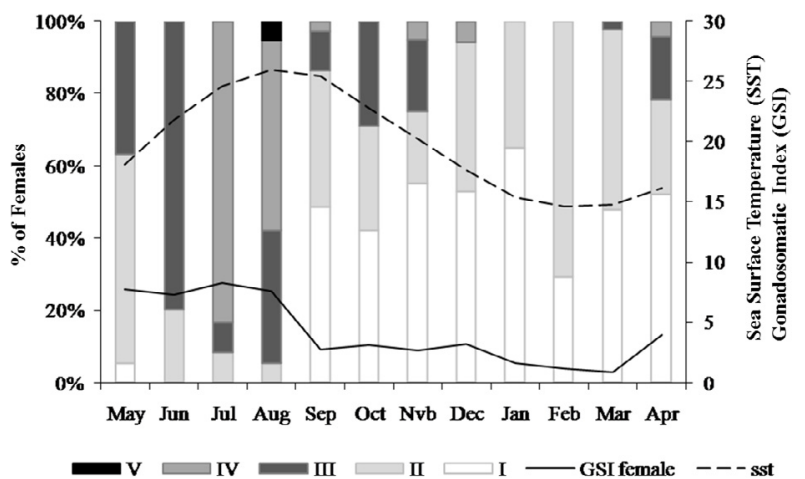

Fig. 5. Spawning phases distribution according to histological staging: Immature, phase I; Developing, phase II; Maturing, phase III; Spawning, phase IV and Spent, phase V. Gonadosomatic index (GSI) values in females (GSI female) and sea surface temperature (SST, in ${ }^{\circ} \mathrm{C}$ ) were also plotted referring to the right axis to have more data to evaluate spawning phase evolution with temperature.

Table 4. The overall percentage of correspondence between macroscopic (MACRO) and histological examinations (MICRO) for each maturity phase; the number of individuals is given in parentheses.

\begin{tabular}{cccccc}
\hline \multirow{2}{*}{ MACRO } & \multicolumn{5}{c}{ MICRO } \\
\cline { 2 - 6 } & I & II & III & IV & V \\
\hline I & $52.43(108)$ & $45.15(93)$ & $1.94(4)$ & $0.49(1)$ & 0.00 \\
II & $10.81(4)$ & $48.65(18)$ & $27.03(10)$ & $13.51(5)$ & 0.00 \\
III & 0.00 & $13.95(6)$ & $67.44(29)$ & $18.60(8)$ & 0.00 \\
IV & 0.00 & $9.09(1)$ & $18.18(2)$ & $63.64(7)$ & $9.09(1)$ \\
V & 0.00 & 0.00 & 0.00 & $100.00(3)$ & 0.00 \\
\hline
\end{tabular}

\subsection{Macroscopic vs. microscopic classification and $L_{50}$ estimation}

According to Table 4, macroscopic examination revealed relevant discrepancies in each maturity phase determination. In immature phase (I), macroscopic identification was misleading in more than $47 \%$ of individuals, mainly misclassified as phase II $(45 \%)$. Developing phase (II) was erroneously indicated in $11 \%$ of samples as phase I, in $27 \%$ of individuals as phase III, and in $13 \%$ of these as phase IV. The major part of ovaries macroscopically classified as maturing (III) appeared to be well recognized $(67.44 \%)$; but $14 \%$ of samples were still developing (II), and $19 \%$ of these were even mature (IV). The percentage of correspondence for spawning phase (IV) was also high $(63 \%)$ as for the previous stage; $18 \%$ of individuals were misclassified as phase III, and $9 \%$ of these as phase V. Finally, spent phase (V) had the highest misclassification value with 0 individuals correctly classified, probably due to the low number of individuals achieving this ovary development phase (Table 4).

According to adopted criteria for the size at first maturity evaluation, the selected spawning period was from April to August. $L_{50}$ value was estimated both for microscopic (15.97 $\mathrm{cm}$ for TL and $3.66 \mathrm{~cm}$ for $\mathrm{CL}$ ) and macroscopic (17.02 cm for TL and $3.98 \mathrm{~cm}$ for CL) spawning phase determination. Results showed $L_{50}$ estimate to be $1 \mathrm{~cm}$ lower when histological evaluation is adopted (Fig. 7).

\section{Discussion}

Use of commercial catches to collect samples could affect results, because sampling strategy is conditioned by selectivity of fishing gears and by a skewed spatial distribution of shrimps in comparison to fishing ground geographical position. However, several studies on caramote prawn reproduction and distribution utilized sampling method (commercial trawlers) and bathymetric ranges as in the present study (Fig. 1), obtaining a size distribution, for both total and carapace length, comparable with present results (i.e., Kevrekidis and Thessalou-Legaki 2006; Turkemen et al. 2007; Vitale et al. 2010; Lumare et al. 2011). Furthermore Conides et al. (2008), which adopted the trammel net, obtained a size distribution (11-21 cm TL) highly overlapping the present data $(9-21.5 \mathrm{~cm}$ $\mathrm{TL})$. Clear differences in size range between sexes confirmed 


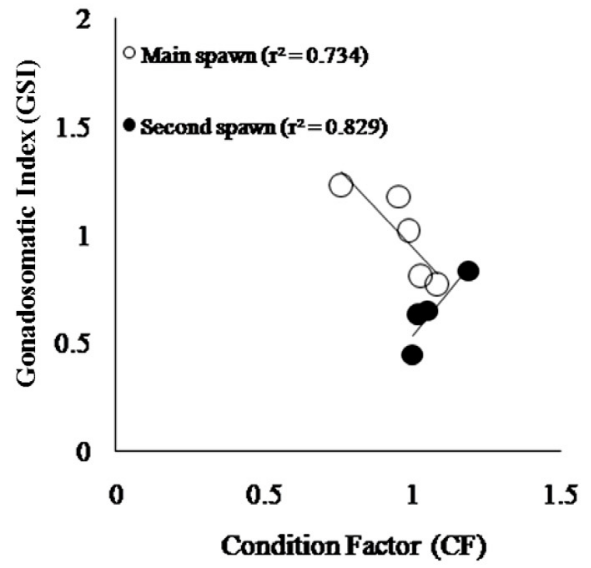

(a)

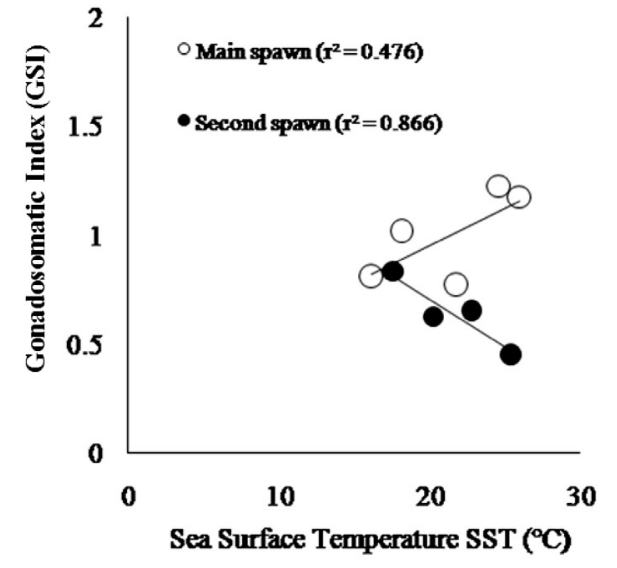

(b)

Fig. 6. (a) Linear relationship between condition factor (CF) and gonadosomatic index (GSI) in caramote prawn males, plotting for the main spawning period (April-August) and for the tail of spawning period (September-December). (b) Linear relationship between gonadosomatic index (GSI) and sea surface temperature (SST, in ${ }^{\circ} \mathrm{C}$ ) in caramote prawn males, plotting for the main spawning period (April-August) and for the tail of spawning period (September-December).

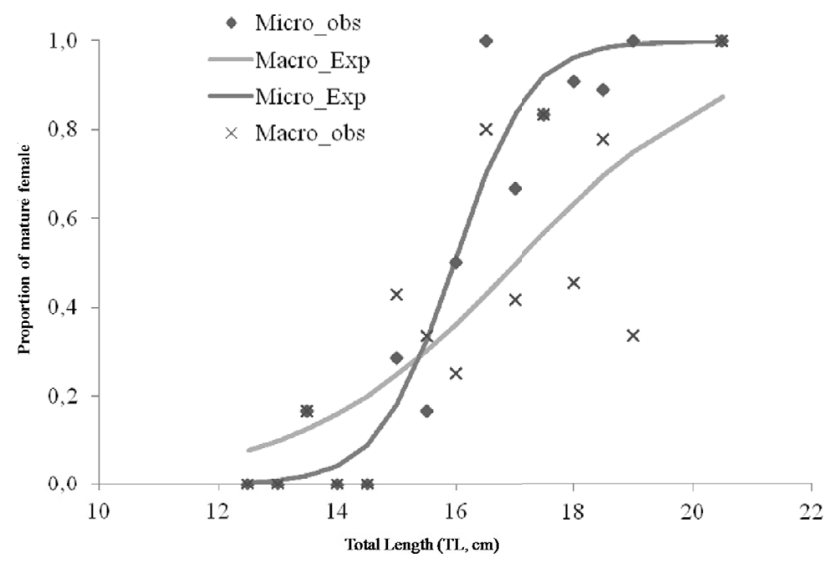

Fig. 7. Maturity ogives for females of caramote prawn from the Tunisian waters: the effect of a macroscopic wrong maturity determination is showed by differences between two curves, obtained respectively by macroscopic and microscopic maturity phase assignment data.

the presence of a sexual dimorphism, already observed by several authors displaying that females reached a greater body length than males (Heldt 1932; Ben Meriem 1993; Kapiris and Conides 2009; Kevrekidis and Thessalou-Legaki 2011). These differences could be explained by higher growth rates and performances in females (Kapiris and Conides 2009; Kevrekidis and Thessalou-Legaki 2011). Differences in length-weight relationship between sexes, which appear mainly due to sexual dimorphism, were also indicated for the same species in different areas of the Mediterranean Sea both for wild individuals (Ishak et al. 1980; Ben Meriem 1995; Conides et al. 2006; Turkmen et al. 2007) and for reared ones (Klaoudatos 1984).

SR monthly trend suggested a predominance of males from May to July during the peak of spawning. Such patterns appeared to be not affected by high variability in the number of monthly sampled individuals, since similar SR trends were observed for penaeid shrimps (Niamaimandi et al. 2008) and for caramote prawn in other Mediterranean areas, such as Italian waters (Lumare et al. 2011) and the Aegean Sea (Kevrekidis and Thessalou-Legaki 2006); these patterns are mainly explained by a migration behaviour due to reproduction (Rodriguez 1987; Conides et al. 2008). However, other causes may affect sudden SR variability, such as the higher females catchability (Kevrekidis and Thessalou-Legaki 2006) or the higher males natural mortality due to mating, as in the case of Penaeus chinensis (Cha et al. 2002). Males were predominant in smaller size classes, while the larger length groups were only composed of females. This could be explained by early onset of sexual maturity in males which reduces energy investment in growth and results in body sizes smaller than for females, as observed in several penaeids species (Ohtomi and Matsuoka 1998; Ben Abdallah et al. 2003; Kim 2005; SainteMarie et al. 2006).

Although the use of GSI for some penaeid prawns was criticized in literature for its controversial results sometimes provided (Courtney et al. 1995), several other authors demonstrated a correspondence between sexual maturation and GSI evolution (Tom and Lewinsohn 1983; Quinitio et al. 1989; Quinitio and Millamena 1992; Othomi et al. 2003), as it was observed for marine fishes (Basilone et al. 2006). In the case of caramote prawn, GSI trend appeared to be a good indicator of the spawning period (Medina et al. 1996; Türkmen and Yilmazyerli 2006; Kücükdermenci and Lok 2012). Assessment of seasonal variability of somatic and gonadic conditions allowed to infer on the reproductive strategy of caramote prawn. For both sexes, seasonal variability of body conditions showed two different levels along the study period, respectively the lower from May to June and the higher, and relatively stable, from July onwards. The role of body conditions did not seem crucial in spawning activity regulation during the peak of spawning, as suggested by similarity of CF values inside and outside reproductive season.

For females, GSI trend displayed a well-defined seasonal spawning pattern with higher egg production during summer, lowering in autumn and falling in winter. Despite this clear GSI trend, somatic condition (CF) appeared not to be directly 


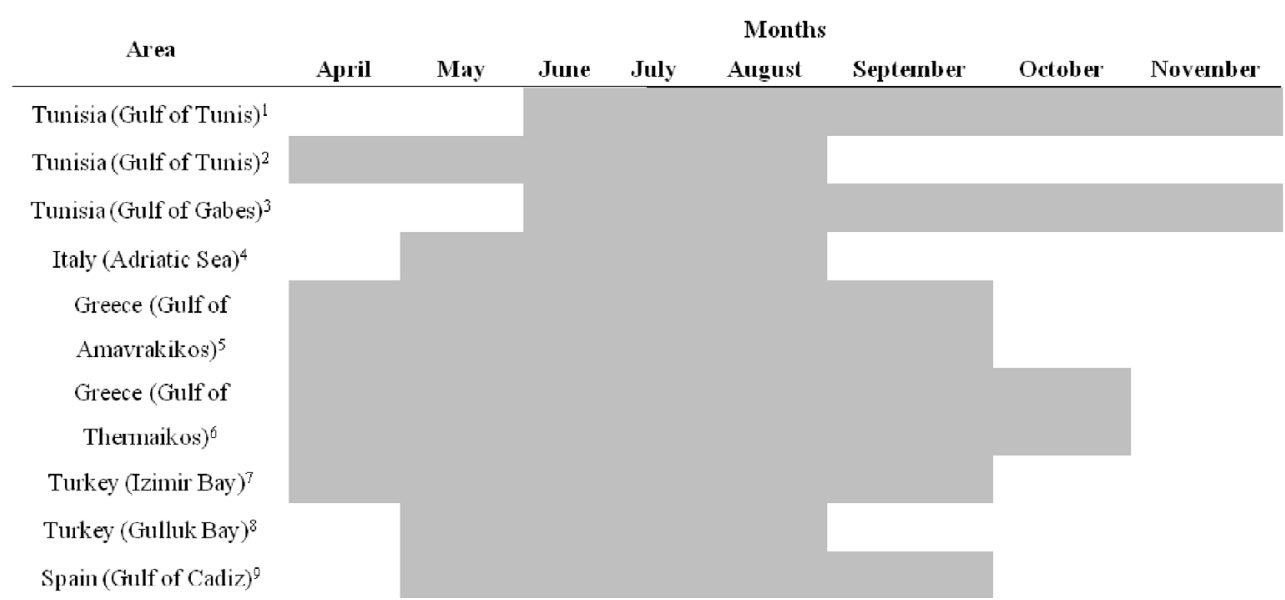

Fig. 8. Several population of caramote prawn in different study areas showed a protracted spawning season of at least five months. 1) Ben Mustafa 1967; 2) Present study; 3) Ben Meriem 1993; 4) Lumare et al. 2011; 5) Conides et al. 2008; 6) Kosmas and Maria 2012; 7) Turkman and Ylmazyerli 2006; 8) Turkmen et al. 2007; Rodríguez 1985.

related with it. Lower values of $\mathrm{CF}$, recorded during spring, suggested that energy investment at the beginning of reproductive season was mainly devoted to gonadic growth. During the peak of spawning (July-August), increase of CF associated with higher GSI values may indicate that this species still feeds during spawning season, thus producing better body conditions. Usually, during spawning season, available energy is devoted to gonadic production, with a depletion of somatic condition. However, in the present study increase of CF suggested a protracted input of energy from feeding along spawning season, and a split of energy allocation between reproduction and body demand. In many crustacean decapods, molt process takes place during reproductive period, explaining the need of energy intake for body growth during spawning season (Adiyoi 1985; Nelson 1991; Parnes et al. 2006).

Caramote females, during autumn and winter, revealed lower values of GSI and abundance of immature individuals, with higher length, weight and good somatic conditions; such combination of results further suggests that energy allocation in the aforesaid period was mainly devoted to body growth. Although body growth appeared to be linked to GSI evolution, no clear relationship was recorded between females GSI and $\mathrm{CF}$, suggesting that maturity pattern was almost independent from body conditions. Therefore, gonadic energy investment and body growth seemed to be at the same time supported by good feeding conditions. Differently from caramote prawn females, in males decreasing linear relationship between GSI and CF data from April to August suggested a more strongly supported mobilization of energy reserve from body to reproduction. Further, from September onwards during the end of spawning season, the relationship between GSI and CF still persisted even with opposite positive sign. In other words, such observations for males further support what already observed for females, the only exception was for body reserves in males, which appeared fully devoted to gonadic growth and to other physiological energy demanding processes, such as the molt, during the main spawning period (April-August) when body conditions became depleted.

Such worse body conditions in males could be also due to an earlier maturation period, as GSI in males starts to in- crease two months earlier than females (Fig. 4b). Such strategy was also showed in Uca nr. minax (Hasek and Felder 2006), in Aristaeomorpha foliacea, and in Aristeus antennatus (Kapiris and Thessalou-Legaki 2008).

Monthly abundance of ovary spawning phases, together with GSI and SST monthly trends, highlighted a protracted spawning period (April-August) with a clear seasonal peak in July-August, occurring simultaneously with the year maximum temperature values in the study area. However, a minor reproductive activity was recorded until December when temperature was lower. Occurrence of spawning peak with the higher sea water temperatures in summer, as also observed in Turkish and Greek waters, confirmed that in the Mediterranean Sea caramote prawn spawning seasons are affected by water temperature (Turkmen et al. 2007; Conides et al. 2008). Otherwise, several studies indicated that thermal stimulus and photoperiod appear as the main input for reproductive activity in prawns (maturation of gonads and migration to reproduction grounds for copulation), so they are extensively used in intensive aquaculture practices (Conides et al. 2008 and reference therein).

Several populations of caramote prawn, inhabiting both Atlantic and Mediterranean waters, showed a protracted spawning period of at least 5 months (Fig. 8). Despite the similar extension of spawning period and the coincidence of spawning peaks in summer, starting and ending of such a period may be different (Fig. 8). This may be probably due to interannual variability of environmental features or spatial variability among areas, as reported for many other penaeid species, which displayed both inter-annual and monthly variations in reproductive activity (Crocos and Van Der Velde 1995; Courtney and Masel 1997; Minagawa et al. 2000; Montgomery et al. 2007; Hossain and Ohtomi 2008).

Although macroscopic gonad evaluation appears to be affected by some limits in accuracy, it allows to determine in short time the spawning phase of a bigger number of samples in comparison with microscopic analysis. Histological ovary preparation provided useful information to validate macroscopic scales, allowing to establish a more reliable maturity classification and spawning period determination. 
Macroscopic reproductive phase determination, as validated by histological analysis of ovaries tissues, showed how the macroscopic classification used (Farmer 1974) may be not always able to discriminate immature and mature (appearance of yolk globules) individuals in crustaceans, as well as reported for several fish species (Stratoudakis et al. 2004; Costa 2009; Ferreri et al. 2009; Khoufi et al. 2014). Comparison of $L_{50}$ estimates for the Tunisian caramote prawn confirmed the importance of microscopic examination to obtain reliable ogives, as data from macroscopic assignment were misleading (Fig. 7). However, both $L_{50}$ results presented sizes similar to values observed in literature: i.e., $17 \mathrm{~cm}$ in the Adriatic Sea (macroscopic examination; Lumare et al. 2011), $18 \mathrm{~cm}$ in the East Ionian Sea (only spawning phase IV by means of macroscopic examination; Conides et al. 2006), $18 \mathrm{~cm}$ in the Aegean Sea (macroscopic examination; Turkmen et al. 2005) and $12 \mathrm{~cm}$ in the Gulf of Cadiz (microscopic examination; Rodríguez 1985). Although discrepancies with literature are mainly related with the Spanish cases studies, such differences may be due to several reasons. For example, as it was reported for some fish species, variability of $L_{50}$ may be linked to latitudinal effects or over-exploitation of stock (Khoufi et al. 2014 and references therein).

Improved knowledge on reproductive features of caramote prawn allows to better understand its reproductive strategy, in order to refine the diagnostic for stock assessment and sustainable management for such species. Indeed, one of the main purpose of stock and fishery management is to maintain sufficient levels of spawning biomass, able to safeguard the correct recruitment degree. Moreover, information about relationship between growth, reproduction and environmental parameters appeared essential also in implementation of aquaculture for caramote prawn and other penaeid species. Finally, results of the present study may provide basic information for future fishery management and forecast in the North and the East of Tunisia, where caramote prawn fishing is currently not regulated.

Acknowledgements. The authors would like to express our thanks to the staff of the Fishing vessel "El Mostakbel" for their help and provision of samples. Our thanks go also to NOAA (National Oceanic and Atmospheric Administration) for their collaboration in placing climatic data available. The authors gratefully acknowledge financial support from the Higher Education Ministry of Tunisia, which allowed us to realise histological analysis at IAMC-CNR (Istituto per l'Ambiente Marino Costiero del Consiglio Nazionale delle Ricerche) U.O.S. of Capo Granitola (Sicily, Italy).

\section{References}

Adiyodi R.G., 1985, Reproduction and its control in the Biology of Crustacea. In: Bliss D.E., Mantel H., (Eds), Integument, Pigments and Hormonal Processes. Academic Press, New York, Vol. 3, pp. 147-216.

Basilone G., Guisande C., Patti B., Mazzola S., Cuttitta A., Bonanno A., Vergara A.R., Maneiro I., 2006, Effect of habitat conditions on reproduction of the European anchovy (Engraulis encrasicolus) in the Strait of Sicily. Fisheries Oceanography 15(4), 271280.
Basilone G., Ganias K., Ferreri R., D’Elia M., Quinci E. M., Mazzola S., Bonanno A., 2015, Application of GAMs and multinomial models to assess the spawning pattern of fishes with daily spawning synchronicity: A case study in the European anchovy (Engraulis encrasicolus) in the central Mediterranean Sea. Fisheries Research 167, 92-100.

Bdioui M., M'Rabet R., Ben Naceur L., Missaoui H., Ben Salem S., 2004, Aspects techniques d'exploitation du métier trémails à crevettes dans le golfe de Gabès. Bulletin de l'Institut National des Sciences et Technologies de la Mer 31, 53-60.

Ben Abdallah O., Jarboui O., Missaoui H., Ben Hadj Hamida N., 2003, Croissance relative, sex-ratio et exploitation de la crevette blanche Metapeneaus monoceros (Fabricus, 1798) du Golfe de Gabes (Tunisie). Bulletin de l'Institut National des sciences et technologies de la Mer Salammbô 30, 49-54.

Ben Meriem S., 1993, Taille de première maturité et période de ponte de Penaeus kerathurus dans le golfe de Gabès, Tunisie (Decapoda, Penaeoidea). Crustaceana 65, 82-96.

Ben Mariem S., 1995, Caractères biométriques de Penaeus kerathurus (Forskäl, 1775) du golfe de Gabes, Tunisie (Decapoda, Penaeidae). Crustaceana 68, 583-596.

Ben Meriem S., 1998, Mortalités (F et M) et analyse des rendements par recrue de Penaeus kerathurus (Forskäl) du golfe de Gabès, Tunisie. In: Lleonart J., (Eds), Dynamique des populations marines. Cahiers Options Méditerranéennes CIHEAM, Zaragoza, pp. 25-34.

Ben Mustapha A., 1967, Observations biologiques sur Penaeus kerathurus (Forskäl, 1775) et étude biométrique. Annales de l'Institut National Scientifique et Technique d'océanographie et de pêche Salammbô 13, 1-101.

Butler G.L., Rowland S.J., 2009, Using underwater cameras to describe the reproductive behavior of the endangered eastern freshwater cod Maccullochella ikei. Ecol. Freshw. Fish. 18, 337-349.

Cha K.H., Oh C.W., Hong S.Y., Park K.Y., 2002, Reproduction and population dynamics of Penaeus chinensis (Decapoda: Penaeidae) on the western coast of Korea, Yellow Sea. Fish. Res. $56,25-36$.

Chaouachi B., Ben Hassine O.K., 1998, Données sur la pêche des crevettes profondes Parapenaeus iongirostris (Lucas, 1846) en Tunisie. In: Lleonart J., (Eds), Dynamique des populations marines, Cahiers Options Méditerranéennes CIHEAM, Zaragoza, pp. 201-213.

Coleman F., Koenig C.C., Collins A., 1996, Reproductive style of shallow water groupers (Pisces: Serranidae) in the eastern Gulf of Mexico and the consequences of fishing spawning aggregations. Environ. Biol. Fishes 47, 129-141.

Conides A., Glamuzina B., Jukdujakovic J., Kapiris K., Papaconstantinou C., Hunter S., 2008, Study of the reproduction of the karamote shrimp Penaeus (Melicertus) kerathurus in the Amvrakikos Gulf, Western Greece. Acta Adriatica 49, 97-106.

Conides A., Glamuzina B., Papaconstantinou C., Kapiris K., 2006, Age, growth, and mortality of the karamote shrimp, Penaeus (Melicertus) kerathurus (Forskäl, 1775) in the East Ionian Sea (Western Greece). Crustaceana 79, 33-52.

Costa A.M., 2009, Macroscopic vs. microscopic identification of the maturity stages of female horse mackerel. ICES J. Marine Sci. 6, 509-516.

Courtney A.J., Masel J.M., 1997, Spawning stock dynamics of two penaeid prawns, Metapenaeus bennetae and Penaeus esculentus in Moreton Bay, Queensland, Australia. Marine Ecol. Progr. Ser. $148,37-47$. 
Courtney A.J., Montgomery S.S., Die D.J., Andrew N.L., Cosgrove M., Blount C., 1995, Maturation in the female eastern king prawn Penaeus plebejus from coastal waters of eastern Australia, and considerations for quantifying egg production in penaeid prawns. Marine Biology 122, 547-556.

Crocos P.J., van der Velde T.D., 1995, Seasonal, spatial and interannual variability in the reproductive dynamics of the grooved tiger prawn Penaeus semisulcatus in Albatros Bay, Gulf of Carpentaria, Australia: the concept of effective spawning. Marine Biology 122, 557-570.

Crocos P.J., Park Y.C., Die D.J., Warburton K., Manson F., 2001, Reproductive dynamics of Endeavour prawns, Metapenaeus endeavor and M. ensis, in Albatros Bay, Gulf of Carpentaria, Australia. Marine Biology 138, 63-75.

Dall, W., Hill, B.J., Rothlisberg, P.C., Staples, D.J., 1990, The biology of the Penaeidae. In: Blaxter J.H.S., Southward A.J. (eds.), Adventure Marine Biology. Academic Press, New York, Vol. 27, pp. 1-489.

Dore I., Frimodt C., 1987, An Illustrated Guide to Shrimp of the World. Osprey Books, Huntington, New York.

FAO 2010, Statistics and Information Service of the Fisheries and Aquaculture Department/Service des statistiques et de l'information du Département des pêches et de l'aquaculture/Servicio de Estadísticas y Información del Departamento de Pesca y Acuicultura. 2012 FAO yearbook. Fishery and Aquaculture Statistics.

Farmer A.S., 1974, The functional morphology of the moth parts and pereiopods of Nephrops norvegicus (L.) (Decapoda:Nephropidae). J. Crust. Biol. 2, 408-417.

Ferreri R., Basilone G., D’Elia M., Traina A., Saborido-Rey F., Mazzola S., 2009, Validation of macroscopic maturity stages according to microscopic histological examination for European anchovy. Marine Ecology 30, 181-187.

de Freitas A.J., 2011, The Penaeoidea of South Africa IV - The Family Penaeidae: Genus Penaeus. In: Oceanographic Research Institute, Investigational Report No. 59., pp. 125.

Garcia, S., le Reste L., 1981, Life cycles dynamics, exploitation and management of coastal penaeid shrimp stocks. FAO Fisheries Technical Paper, 203, Rome, 215 pp.

Gil M.M., Grau A., Basilone G., Ferreri R., Palmer M. 2013. Reproductive strategy and fecundity of meagre Argyrosomus regius Asso, 1801 (Pisces: Sciaenidae): implication for restocking programs. Sci. Mar. 77, 105-118.

Hasek B.E., Felder D.L., 2006, Biochemical contents of the ovary and hepatopancreas of Ucalongisignalis and Ucanraminax. Scientia Marina 70, 505-517.

Heldt J.H., 1932, Sur quelques différences sexuelles (Coloration, Taille, Rostre) chez deux crevettes tunisiennes: Panaeus caramote Risso et Parapenaeus longirostris Lucas. Bulletin de la Station Océanographique Salammbô 27, 1-25.

Heldt J.H., 1938, La reproduction chez les Crustacés Décapodes de la famille des Pénéides. Annale de l'Institut Océanographique Paris 28, 1-206.

Holthuis L.B., F.A.O., 1980, Species catalogue, shrimps and prawns of the world. An annotated catalogue of species of interest to fisheries. FAO Fisheries Synopsis, Vol. 125 (1), 271 p.

Hossain M.Y., Ohtomi J., 2008, Reproductive biology of the southern rough shrimp Trachysalambria curvirostris (Penaeidae) in Kagoshima Bay, southern Japan. J. Crust. Biol. 28, 607-612.

ICES (International Council for the Exploration of the Sea), 2008, Report of the Workshop on Maturity Ogive Estimation for Stock Assessment. WKMOG-ICES, Lisbon, Portugal, CM2008/ACOM-33, 72 pp.
Ishak M.M., Alsayes A.A., Abdel Razer F.A., 1980, Bionomics of Penaeus (Melicertus kerathurus) transplanted into lake Quarum (Egypt). Aquaculture 21, 365-374.

Joaquim S., Matias D., Lopes B., Arnold W.S., Gaspar M.B., 2008, The reproductive cycle of white clam Spisula solida (L.) (Mollusca: Bivalvia): Implications for aquaculture and wild stock management. Aquaculture 281, 43-48.

Kapiris K., Conides A., 2009, Studies on the allometric growth of the caramote prawn Melicertus kerathurus (Decapoda: Penaeidae) in the Western Greece (E. Mediterranean). Med. Mar. Sci. 10, 25 34.

Kapiris K., Thessalou-Legaki M., 2008, Comparative Reproduction Aspects of the Deep-water Shrimps Aristaeomorpha foliacea and Aristeus antennatus (Decapoda, Aristeidae) in the Greek Ionian Sea (Eastern Mediterranean). Int. J. Zool. 2009, 9 p.

Kevrekidis K., Thessalou-Legaki M., 2006, Catch rates, size structure and sex ratio of Melicertus kerathurus (Decapoda: Penaeidae) from an Aegean Sea trawl fishery. Fish. Res. 80, 270-279.

Kevrekidis K., Thessalou-Legaki M., 2011, Population dynamics of Melicertus kerathurus (Decapoda: Penaeidae) in Thermaikos Gulf (N. Aegean Sea). Fish. Res. 107, 46-58.

Kevrekidis K., Thessalou-Legaki M., 2013, Reproductive biology of the prawn Melicertus kerathurus (Decapoda: Penaeidae) in Thermaikos Gulf (N. Aegean Sea). Helgoland Marine Res. 67, $17-31$.

Khoufi W., Ferreri R., Jaziri H., El Fehri S., Gargano A., Mangano S., Ben Meriem S., Romdhane M.S., Bonanno A., Basilone G., 2014, Reproductive potential aspects in hake (Merluccius merluccius) in the central Mediterranean Sea: first observations from Tunisian waters. J. Marine Biol. Assoc. UK 94, 1545-1556.

Kim S., 2005, Population structure, growth, mortality, and size at sexual maturity of Palaemon gravieri (Decapoda: Caridea: Palaemonidae). J. Crust. Biol. 25, 226-232.

Klaoudatos S., 1984, Contribution to the biological cycle of Penaeus kerathurus (Forskäl, 1775) in Greek waters, its reproduction and breeding under controlled conditions. Institute of oceanographic and fisheries research, Ag. Kosmas, Hellenikon, Athens Greece, Special Publication 9, 1-238.

Kücükdermenci A., Lok A., 2012, An investigation on ovarian development of grooved shrimp Melicertus kerathurus in Izmir Bay, Turkey. J. Mar. Biol. Assoc. UK 92, 531-538.

Le Cren E.D., 1951, The length-weight relationship and seasonal cycle in gonad weight and condition in the perch (Perca fluviatilis). J. Animal Ecol. 20, 201-219.

Lumare F., 1998, Crostacei Peneidi Tecnica E Gestione Dell'Allevamento. Manuale Di Divulgazione Serie Acquacoltura. ESAV, Roma, Vol. 4, 187 p.

Lumare D., Lumare L., Vitale S., Lumare F., 2011, Reproduction of the caramote shrimp Melicertus kerathurus (Decapoda:Penaeidae) in the South Adriatic Sea (south-eastern coast of Italy). Crustaceana 84, 293-305.

Marshall C.T., O’Brien L., Tomkiewicz J., 2003, Developing alternative indices of reproductive potential for use in fisheries management: case studies for stocks spanning an information gradient. J. Northw. Atl. Fish. Sci. 33, 161-190.

McBride R.S., Somarakis S., Fitzhugh G.R., Albert A., Yaragina N.A., Wuenschel M.J., Alonso-Fernandez A., Basilone G. 2015, Energy acquisition and allocation to egg production in relation to fish reproductive strategies. Fish and Fisheries 16, $23-57$.

Medina A., Vila Y., Mourente G., Rodriguez A., 1996, A comparative study of the ovarian development in wild and pond-reared shrimp, Penaeus kerathurus (Forskäl, 1775). Aquaculture 148, 63-75. 
Minagawa M., Yasumoto S., Ariyoshi T., Umemoto T., Ueda T., 2000, Interannual, seasonal, local and body size variations in reproduction of the prawn Penaeus (Marsupenaeus) japonicas (Crustacea:Decapoda: Penaeidae) in the Ariake Sea and Tachibana Bay. Japan Mar. Biol. 136, 223-231.

Montgomery S.S., Courtney A.J., Blount C., Stewart J., Die D.J., Cosgrove M., O'Neil M.F., 2007, Patterns in the distribution and abundance of female eastern king prawns, Melicertus plebejus (Hess, 1865), capable of spawning and reproductive potential in waters of eastern Australia. Fish. Res. 88, 80-87.

Munga C.N., Mwangi S., Ong'anda H., Ruwa R., Manyala J., Groeneveld J.C., Edward Kimani E., Vanreusel A., 2013, Species composition, distribution patterns and population structure of penaeid shrimps in Malindi-Ungwana Bay, Kenya, based on experimental bottom trawl surveys. Fish. Res. 147, 93-102.

Nelson K., 1991, Scheduling of reproduction in relation to molting and growth in malacostracan crustaceans. In: Wenner A., Kuris A. (Eds.). Crustacean Issues. Crustacean Egg Production. Balkema Press, Rotterdam, pp. 77-113

Niamaimandi N., Aziz A., SitiKhalijah D., CheRoos S., Kiabi B., 2008, Reproductive biology of the green tiger prawn (Penaeus semisulcatus) in coastal waters of Bushehr, Persian Gulf. ICES J. Mar. Sci. 65, 1593-1599.

Ohtomi J., Matsuoka T., 1998, Reproduction and growth of jackknife shrimp, Haliporoides sibogae, off south-western Kyushu Japan. Fish. Res. 38, 271-281.

Ohtomi J., Tashiro T., Atsuchi S., Kohno N., 2003, Comparison of spatiotemporal patterns in reproduction of the kuruma prawn Marsupenaeus japonicus between two regions having different geographic conditions in Kyushu, southern Japan. Fish. Sci. 69, 505-519.

Parnes S., Raviv S., Shechter A., Sagi A., 2006, Males also have their time of the month: Cyclic disposal of old spermatophores, timed by the molt cycle, in a marine shrimp. J. Exp. Biol. 209, 49744983.

Pillay T.R., 1964, An aid to identification of the Mysid cat fishes of Bangladesh. Bangladesh J. Zool. 2, 1-12.

Potter I.C., Chrystal P.J., Loneragan N.R., 1983, The biology of the blue manna crab P. pelagicus in an Australian estuary. Marine Biology 78, 75-85.

Quinitio E.T., Millamena O.M., 1992, Ovarian changes and femalespecific protein levels during sexual maturation of the white shrimp Penaeus indicus. Israeli J. Aquaculture-Bamidgeh 44, $7-12$.

Quinitio E.T., Hara A., Yamauchi K., Mizushima T., Fuji A., 1989, Identification and characterization of vitellin in a hermaphrodite shrimp, Pandalus kessleri. Comp. Biochem. Physiol. B 94, 44-451.
Reñones O., Grau A., Mas X., Riera F., Saborido-Rey F., 2010, Reproductive pattern of an exploited dusky grouper Epinephelus marginatus (Lowe, 1834) (Pisces, Serranidae) population in the western Mediterranean. Scientia Marina 74, 523-537.

Roa R., Ernst B., Tapia F., 1999, Estimation of size at sexual maturity: an evaluation of analytical and resampling procedures. Fish. Bull. US 97, 570-580.

Rodrígeuz A., 1977, Contribución al conocimiento de la biología y pesca del langostino, Penaeus kerathurus (Forskäl, 1775) del golfo de Cádiz (región sudatlántica española). Investigacion Pesquera 41, 603-635.

Rodríguez A., 1985, Biología del langostino Penaeus kerathurus (Forskäl, 1755) del golfo de Cádiz. I. Reproducción. Investigacion Pesquera. 49, 581-595.

Rodríguez A., 1987, Biología del langostino Penaeus kerathurus (Forskäl, 1755) del golfo de Cádiz. III: Biometría, edad y cresimiento. Investigacion Pesquera 51, 23-37.

Sainte-Marie B., Berube I., Brillon S., Hazel F., 2006, Observations on the growth of the sculptured shrimp Sclerocrangon boreas (Decapoda:Caridea). J. Crust. Biol. 26, 55-62.

San Feliu J.M., Munoz E., Amat E., Ramos J., Peffa J., Sanz A., 1976, Techniques stimulation de la ponte et d'élevage de larves de Crustacés et de poissons. Stud. Rev. GFCM 55, 1-34.

Stratoudakis Y, Bernal M, Uriarte A, 2004, The DEPM estimation of spawning-stock biomass for sardine and anchovy. ICES Cooperative Research Report, Vol. 268 (i), 91 p.

Tom M., Lewinsohn Ch., 1983, Aspects of the benthic life cycle of Penaeus (Melicertus) japonicas Bate (Crustacea: Decapoda) along the southeastern coast of the Mediterranean. Fish. Res. 2, 89-101.

Trippel E.A., 1999, Estimation of stock reproductive potential: history and challenges for Canadian Atlantic gadoid stock assessments. J. Northw. Atl. Fish. Sci. 25, 61-81.

Türkmen G., Yilmazyerli H., 2006, Some biological aspects of Melicertus kerathurus (Forskäl, 1775) (Decapoda: Penaeidae) inhabiting Izmir Bay (Aegean sea), Turkey. Crustaceana 79, 583-591.

Türkmen G., Õzden O., Yilmazyerli H., Saygi H., 2005, A study on factors influencing emigration and some morphometric traits of Penaeus (Melicertus) kerathurus (Forskäl, 1775) in Sufa (Homa). Lagoon. Ekoloji 56, 16-22.

Türkmen G., Õzden O., Parug S., Akalin S., 2007, Some reproductive aspects of Melicertus kerathurus (Forskäl, 1775) (Decapoda: Penaeidae) inhabiting the Gulluk Bay (Aegean Sea) of Turkey. J. Appl. Biol. Sci. 1, 69-74.

Zitari-Chatti R., Chatti N., Elouaer A., Said K., 2008, Genetic variation and population structure of the caramote prawn Penaeus kerathurus (Forskäl) from the eastern and western Mediterranean coasts in Tunisia. Aquacult. Res. 39, 70-76. 